\title{
Chemospecific and Regioselective Ethereal Methyl-Oxygen Bond Cleavage Behavior of Aroylated Dimethoxynaphthalenes by Combined Action of $\mathrm{AlCl}_{3}$ and Aroyl Group
}

\author{
Akiko Okamoto, Ryosuke Mitsui, Shoji Watanabe, Takahiro Tsubouchi, Noriyuki Yonezawa \\ Departmentof Organic and Polymer Materials Chemistry, Tokyo University of Agriculture and Technology, Koganei, Japan \\ Email: aokamoto@cc.tuat.ac.jp
}

Received July 24, 2012; revised August 26, 2012; accepted September 3, 2012

\begin{abstract}
$\mathrm{AlCl}_{3}$-mediated cleavage of ethereal methyl-oxygen bond in aroylated 2,7-dimethoxynaphthalene compounds proceeds chemospecifically and regioselectively. The ethereal bond at the $\beta(2)$-position of 1-monoaroylated 2,7-dimeth-oxynaphthalene is cleaved readily and predominantly against the $\beta(7)$-position, whereas scission of $\beta$-ethereal bonds of 1,8-diaroylated 2,7-dimethoxynaphthalene hardly undergoes like the non-aroylated mother frame compound of 2,7dimethoxynaphthalene.
\end{abstract}

Keywords: Aroylated 2,7-Dialkoxynaphthalene; Chemospecific and Regioselective Scission of Ethereal Alkyl-Oxygen Bond; Combined Action of $\mathrm{AlCl}_{3}$ and Aroyl Group; Neighboring Group Effect

\section{Introduction}

Congested molecular units having non-coplanar alignment of aromatic rings such as biphenyl, binaphthyl, and other poly (aromatic rings) compounds have been in the limelight for building block of functional molecules and polymers [1-4]. Recently, the authors' group has found that 2,7-dialkoxynaphthalenes readily undertake acidmediated diaroylation with high peri-regioselectivity to give 1-aroyl and 1,8-diaroyl-2,7-dialkoxynaphthalenes in satisfactory yields $[5,6]$. In crystal, the aroyl group of the resulting molecules attaches to the naphthalene ring as nearly perpendicular manner and for diaroylated derivatives two aroyl groups are situated in opposite directions (anti-orientation) [7-9]. The authors' group has integrated the naphthalene-1,8-bis(carbonylarylene) unit into poly(arylene ether ketone) backbone and reported unique solubility tendency to organic solvents and characteristic thermal behavior of the resulting polymers with interpretation in relation to the spatial organization of the repeating unit [10]. In addition, some curious reactions of the 2,7-dimethoxynaphthalene and its derivatives such as reversible aroylation depending on Brønsted acid strength [5] and dual aroylation mediated by Lewis acid [6] are also revealed during the studies on aroylation of naphthalene derivatives.

In this article, the authors introduce Methyl-oxygen bond cleavage behavior of $\beta$-ethereal substituent in aroylated dimethoxynaphthalenes by the combined action of $\mathrm{AlCl}_{3}$ and aroyl group and discuss the regioselectivity and the chemospecificity based on the comparison of the corresponding reaction behaviors among the homologous and analogous dialkoxynaphthalene molecules.

As well known methyl aryl ether generally resists acid-mediated Methyl-oxygen bond cleavage. So deprotection of methyl group from methoxyarenes needs specific reagents such as iodotrimethylsilane with Lewis acids, or $\mathrm{BBr}_{3}$ in place of $\mathrm{AlCl}_{3}$, which has almost no potential for this purpose [11-14]. Furthermore, the $\mathrm{BBr}_{3}$-mediated cleavage often suffers from low regioselectivity. Therefore, effective and regioselective cleavage of methyl aryl ether by $\mathrm{AlCl}_{3}$ is of interest.

\section{Results and Discussion}

Table 1 shows the results of $\mathrm{AlCl}_{3}$-mediated ether-cleavage reaction of 1-monoaroyl-2,7-dimethoxynaphthalene (1aa) in refluxing $\mathrm{CH}_{2} \mathrm{Cl}_{2}$ solutions. The methyl-oxygen bond in 2-methoxy group of 1-monoaroylnaphthalene 1aa was cleaved in the presence of three equimolar amounts of $\mathrm{AlCl}_{3}$ or more (Entries 1 - 6). Using of five equimolar amounts of $\mathrm{AlCl}_{3}$ quantitatively yielded 2-hydroxy-7-methoxy product 2ba (Entry 5). The exclusive scission of 2-methoxy moiety leaving the other 
Table 1. Ethereal Methyl-oxygen bond cleavage reaction of 1-monoaroylnaphthalene 1 aa by $\mathrm{AlCl}_{3}{ }^{[\mathrm{a}]}$.

\begin{tabular}{ccccc} 
Entry & $\mathrm{AlCl}_{3}$ & \multicolumn{3}{c}{ Product Distribution $(\%)^{[b]}$} \\
\hline 1 & 0.1 & 99 & $1 / 0$ & 0 \\
2 & 0.2 & 97 & $3 / 0$ & 0 \\
3 & 0.3 & 88 & $12 / 0$ & 0 \\
4 & 0.4 & 27 & $73 / 0$ & 0 \\
5 & 0.5 & 2 & $98(97) / 0$ & 0 \\
6 & 1.0 & 1 & $99 / 0$ & 0 \\
\hline
\end{tabular}

${ }^{[a]}$ Reaction conditions: 1-Monoaroylnaphthalene 1aa (0.1 mmol), $\mathrm{AlCl}_{3}(0.1$ $1.0 \mathrm{mmol}), \mathrm{CH}_{2} \mathrm{Cl}_{2}(0.25 \mathrm{ml})$, reflux, $30 \mathrm{~min}, \mathrm{~N}_{2}$ atmosphere; ${ }^{[\mathrm{b}]}$ Calculated on the basis of ${ }^{1} \mathrm{H}$ NMR spectra. Isolated yield is given in parentheses.

$\beta$-ethereal substituent of 7-methoxy group unchanged was achieved even when ten equimolar amounts of $\mathrm{AlCl}_{3}$ were employed against substrate 1aa (Entry 6).

Table 2 presents the results of treatment of non-aroylated mother frame molecule of 2,7-dimethoxynaphthalene (3aa) and the analogous molecule of 3-monoaroyl2,7-dimethoxynaphthalene 5aa with $\mathrm{AlCl}_{3}$. Dimethoxynaphthalene (3aa) essentially gave none of alkyl ethercleaved products (Entries 1 and 2). On the other hand, Methyl-oxygen bond in 3-monoaroyl-2,7-dimetoxy-naphthalene 5aa was readily cleaved at the 2-position leaving $\beta(7)$-methoxy group unchanged as well as 1-monoaroyl- 2,7-dimethoxynaphthalene 1aa (Entries 3 and 4).

The results of the reaction of monoaroyl-2,7-dimethoxynaphthalenes (1aa and 5aa) and the ketonic-carbonyl-free analogue, 2,7-dimethoxynaphthalene (3aa), obviously indicate that the ether cleavage reaction of the monoaroyl-2,7-dimethoxynaphthalenes proceeds chemospecifically and regioselectively. Regioselective methyloxygen bond cleavage at 2-position of monoaroyl-2,7dimethoxynaphthalenes 1aa and 5aa apparently demonstrates the presence of the neighboring effect of the aroyl group.

Contrarily, no methyl-oxygen bond cleavage proceeded for 1,8-diaroyl-2,7-dimethoxynaphthalene (7aa) under the similar reaction conditions (Table 3, Entry 1). In refluxing $\mathrm{CH}_{2} \mathrm{ClCH}_{2} \mathrm{Cl}$ solution, only a trace amount of halfly ether-cleaved product 8ba was detected (Entry 2). The ether cleavage reaction proceeded still scarcely even when ten equimolar amounts of $\mathrm{AlCl}_{3}$ were employed (Entry 3). In refluxing toluene solution, 1,8-diaroyl-2,7-dimethoxynaphthalene 7aa gave unidentified compounds with trace amounts of halfly and dually methyl ether-cleaved products 8ba and 8bb (Entry $4)$.
Table 2. Ethereal Methyl-oxygen bond cleavage reactionof dimethoxynaphthalene analogues $3 \mathrm{aa} / 5 \mathrm{aa}$ by $\mathrm{AlCl}_{3}{ }^{[\mathrm{a}]}$.

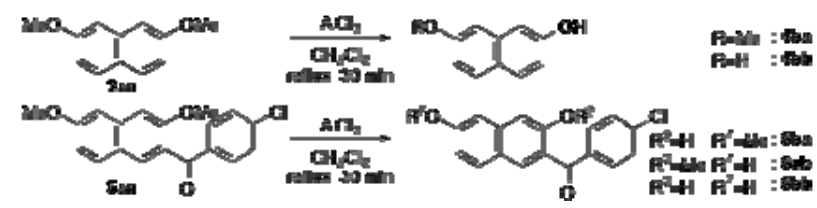

\begin{tabular}{ccccccc}
\hline \multirow{2}{*}{ Entry } & \multirow{2}{*}{ Substrate } & $\mathrm{AlCl}_{3}$ & \multicolumn{4}{c}{ Product Distribution (\%) ${ }^{[\mathrm{b}]}$} \\
\cline { 4 - 7 } & & & 3aa 5aa & 4ba & 6ba / 6ab & 4bb 6bb \\
\hline 1 & 3aa & 0.5 & 100 & 0 & & 0 \\
2 & 3aa & 1.0 & 100 & 0 & & 0 \\
3 & 5aa & 0.5 & 0 & & $97(81) / 2$ & 1 \\
4 & 5aa & 1.0 & 0 & & $99 / 0$ & 1 \\
\hline
\end{tabular}

${ }^{[a]}$ Reaction conditions: Dimethoxynaphthalene analogue 3aa or 5aa $(0.1$ $\mathrm{mmol}), \mathrm{AlCl}_{3}(0.5 \mathrm{mmol}$ or $1.0 \mathrm{mmol}), \mathrm{CH}_{2} \mathrm{Cl}_{2}(0.25 \mathrm{ml})$, reflux, $30 \mathrm{~min}, \mathrm{~N}_{2}$ atmos- phere; ${ }^{[\mathrm{b}}$ Calculated on the basis of ${ }^{1} \mathrm{H}$ NMR spectra.

Table 3. Ethereal Methyl-oxygen bond cleavagereaction of 1,8-diaroylnaphthalene 7 aa by $\mathrm{AlCl}_{3}{ }^{\text {[a] }}$.
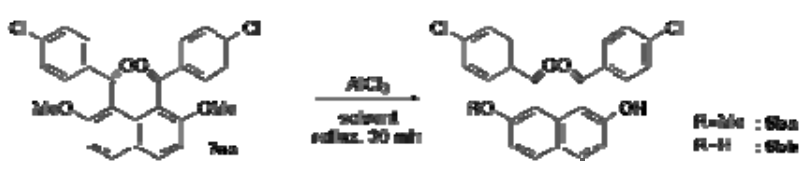

\begin{tabular}{cccccc}
\hline \multirow{2}{*}{ Entry } & \multirow{2}{*}{$\begin{array}{c}\mathrm{AlCl}_{3} \\
(\mathrm{mmol})\end{array}$} & solvent & \multicolumn{3}{c}{ Product Distribution $(\%)^{[\mathrm{b}, \mathrm{c}]}$} \\
\cline { 4 - 6 } & 0.5 & $\mathrm{CH}_{2} \mathrm{Cl}_{2}$ & 100 & 0 & 0 \\
\hline 1 & 0.5 & $\mathbf{8 b a}$ & $\mathbf{8 b b}$ \\
2 & 0.5 & $\mathrm{CH}_{2} \mathrm{ClCH}_{2} \mathrm{Cl}$ & 97 & 3 & 0 \\
3 & 1.0 & $\mathrm{CH}_{2} \mathrm{ClCH}_{2} \mathrm{Cl}$ & 91 & 9 & 0 \\
$4^{[\mathrm{d}]}$ & 0.5 & toluene & $3^{[\mathrm{cc}]}$ & $8^{[\mathrm{c}]}$ & $9^{[\mathrm{c}]}$ \\
\hline
\end{tabular}

${ }^{[\mathrm{a}]}$ Reaction conditions: 1,8-Diaroylnaphthalene 7aa $(0.1 \mathrm{mmol}), \mathrm{AlCl}_{3}(0.5$ $\mathrm{mmol}$ or $1.0 \mathrm{mmol}$ ), solvent (dichloromethane, 1,2-dichloroethane, or toluene; $0.25 \mathrm{ml}$ ), reflux, $30 \mathrm{~min}, \mathrm{~N}_{2}$ atmosphere; ${ }^{[b]}$ Calculated on the basis of ${ }^{1} \mathrm{H}$ NMR spectra; ${ }^{[c]}$ Isolated yields; ${ }^{[\mathrm{d]}}$ Unidentified compounds were included.

The distinct behavior that contrary to complete cleavage of $\beta(2)$-methyl ether bond of 1-monoaroyl-2,7-dimethoxynaphthalene 1aa, the $\beta$-methyl ether bonds of 1,8-diaroyl-2,7-dimethoxynaphthalene 7aa were essentially unchanged indicates the plausible origination of the chemospecificity from the facility of formation of the required conformation for methyl ether bond cleavage. The required conformation still remains indeterminable, however, the probable situation of $\mathrm{AlCl}_{3}$ between ketonic carbonyl oxygen atom and ether oxygen atom might promote the scission of methyl-oxygen bond. In the case of 1,8-diaroyl-2,7-dimethoxynaphthalene 7aa, the formation of the required conformation is presumably obstructed sterically compared to 1- and 3-monoaroy- lated naphthalene derivatives.

The ethyl-oxygen bond cleavage reactions carried out against the corresponding diethoxynaphthalene homologues (Table 4-6) manifest the essentially similar reaction behaviors to those of 2,7-dimethoxynaphthalene 
Table 4. Ethereal ethyl-oxygen bond cleavage reaction of 1-monoaroylated naphthalene 1cc by $\mathrm{AlCl}_{3}{ }^{[\mathrm{a}]}$.

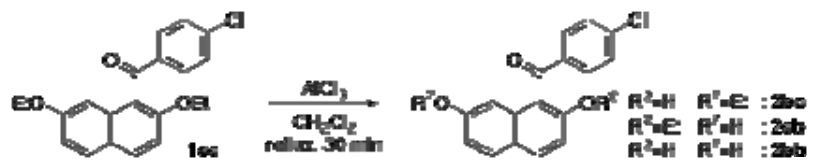

\begin{tabular}{ccccc}
\hline \multirow{2}{*}{ Entry } & $\mathrm{AlCl}_{3}$ & \multicolumn{3}{c}{ Product Distribution (\%) } \\
\cline { 3 - 5 } & $(\mathrm{mmol})$ & 1cc & 2bc/2cb & 2bb \\
\hline 1 & 0.3 & 28 & $72 / 0$ & 0 \\
2 & 0.5 & 0 & $86(80) / 0$ & $14(12)$ \\
3 & 1.0 & 0 & $54 / 0$ & 46 \\
\hline
\end{tabular}

${ }^{\text {[a] }}$ Reaction conditions: 1-Monoaroylated naphthalene $1 \mathrm{cc}(0.1 \mathrm{mmol}), \mathrm{AlCl}_{3}$ $(0.1$ - $1.0 \mathrm{mmol}), \mathrm{CH}_{2} \mathrm{Cl}_{2}(0.25 \mathrm{ml})$, reflux, $30 \mathrm{~min}, \mathrm{~N}_{2}$ atmosphere; ${ }^{[b]}$ Calculated on the basis of ${ }^{1} \mathrm{H}$ NMR spectra. Isolated yields are given in parentheses.

Table 5. Ethereal ethyl-oxygen bond cleavage reaction of diethoxynaphthalene analogues $3 \mathrm{cc} / 5 \mathrm{cc}$ by $\mathrm{AlCl}_{3}{ }^{[\mathrm{a}]}$.

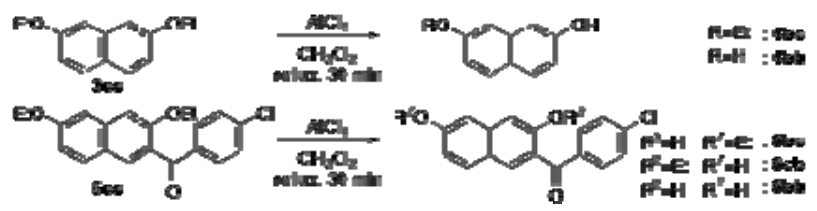

\begin{tabular}{ccccccc}
\hline \multirow{2}{*}{ Entry } & \multirow{2}{*}{$\begin{array}{c}\text { Sub- } \\
\text { strate }\end{array}$} & $\mathrm{AlCl}_{3}$ & \multicolumn{4}{c}{ Product Distribution (\%) } \\
\cline { 4 - 7 } & $(\mathrm{mmol})$ & 3cc 5cc & 4bc & $\mathbf{6 b c / 6 c b}$ & 4bb 6bb \\
\hline 1 & $3 \mathbf{c c}$ & 0.5 & 100 & 0 & - & 0 \\
2 & $3 \mathbf{c c}$ & 1.0 & 96 & 4 & - & 0 \\
3 & $\mathbf{5 c c}$ & 0.5 & 0 & - & $54(54) / 0$ & $46(38)$ \\
4 & $\mathbf{5 c c}$ & 1.0 & 0 & - & $22(22) / 0$ & $78(77)$ \\
\hline
\end{tabular}

${ }^{[a]}$ Reaction conditions: Dialkoxynaphthalene analogue $3 \mathrm{cc}$ or $5 \mathrm{cc}(0.1 \mathrm{mmol})$, $\mathrm{AlCl}_{3}(0.5 \mathrm{mmol}$ or $1.0 \mathrm{mmol}), \mathrm{CH}_{2} \mathrm{Cl}_{2}(0.25 \mathrm{ml})$, reflux, $30 \mathrm{~min}, \mathrm{~N}_{2}$ atmosphere; ${ }^{[b]}$ Calculated on the basis of ${ }^{1} \mathrm{H}$ NMR spectra. Isolated yields are given in parentheses.

analogues (1aa, 3aa, 5aa, and 7aa). Ethyl-oxygen bonds in 1-mono, 3-mono, and 1,8-diaroylnaphthalenes were somewhat easily cleaved than the methyl-oxygen bonds in the corresponding homologous molecules. According to the reaction conditions, halfly ether-cleaved products were obtained quantitatively or mixtures with dihydroxy derivatives were yielded. For example, 1-monoaroylated 2-hydroxy-7-ethoxynaphthalene (2bc) was solely formed by use of a smaller amount of $\mathrm{AlCl}_{3}$ (Table 4, Entry 1 vs. 2). However, half ethyl ether cleavage of 1,8-diaroylated 2,7-diethoxynaphthalene (7cc) is rather difficult even under mild conditions (Table 6, Entries 2 and 6). The results of the cleavage reaction of unsymmetrically dialkoxylated molecule of 1,8-diaroyl-2-ethoxy-7-methoxy naphthalene (7ca) suggest that the methyl-oxygen bond cleavage is promoted after the cleavage of ethoxy group has completed (Table 6). In refluxing $\mathrm{CH}_{2} \mathrm{ClCH}_{2} \mathrm{Cl}$ solution, the ethyl-oxygen bond of 1,8-diaroyl-2-ethoxy-7-methoxynaphthalene (7ca) was cleaved in preference to the
Table 6. Alkyl ether cleavage reaction of 1,8-diaroylated naphthalene 7cc/7ca by $\mathrm{AlCl}_{3}{ }^{\text {[a] }}$.

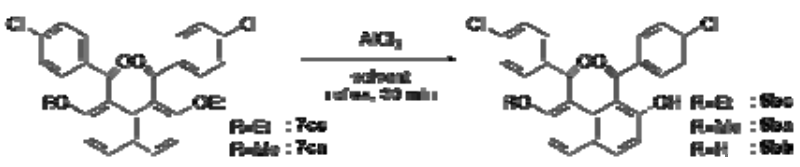

\begin{tabular}{cccccccc}
\hline \multirow{2}{*}{ Entry } & $\mathbf{7}$ & \multirow{2}{*}{$\begin{array}{c}\mathrm{AlCl}_{3} \\
(\mathrm{mmol})\end{array}$} & Solvent & \multicolumn{5}{c}{ Product Distribution $(\%)^{[\mathrm{b}]}$} \\
\cline { 5 - 8 } & & & $\mathbf{7 c c} 7 \mathbf{7 c a}$ & $\mathbf{8 b c}$ & $\mathbf{8 b a}$ & $\mathbf{8 b b}$ \\
\hline 1 & $\mathbf{c c}$ & 0.5 & $\mathrm{CH}_{2} \mathrm{Cl}_{2}$ & 90 & 5 & & 5 \\
2 & $\mathbf{c c}$ & 1.0 & $\mathrm{CH}_{2} \mathrm{Cl}_{2}$ & 77 & 6 & & 17 \\
3 & $\mathbf{c a}$ & 0.5 & $\mathrm{CH}_{2} \mathrm{Cl}_{2}$ & 100 & 0 & 0 & 0 \\
4 & $\mathbf{c c}$ & 0.5 & $\mathrm{CH}_{2} \mathrm{ClCH}_{2} \mathrm{Cl}$ & 43 & $35(34)$ & & 22 \\
5 & $\mathbf{c c}$ & 1.0 & $\mathrm{CH}_{2} \mathrm{ClCH}_{2} \mathrm{Cl}$ & 0 & 0 & & 100 \\
$6[\mathrm{c}]$ & $\mathbf{c c}$ & 1.0 & $\mathrm{CH}_{2} \mathrm{ClCH}_{2} \mathrm{Cl}$ & 33 & 33 & & 34 \\
7 & $\mathbf{c a}$ & 0.5 & $\mathrm{CH}_{2} \mathrm{ClCH}_{2} \mathrm{Cl}$ & 46 & 0 & 42 & 12 \\
8 & $\mathbf{c a}$ & 1.0 & $\mathrm{CH}_{2} \mathrm{ClCH}_{2} \mathrm{Cl}$ & 15 & 0 & $70(67)$ & 15 \\
9 & $\mathbf{c c}$ & 0.5 & toluene & 0 & 0 & & $100(95)$ \\
10 & ca & 0.5 & toluene & 0 & 7 & 0 & 93 \\
\hline
\end{tabular}

${ }^{[\mathrm{a}]}$ Reaction conditions: 1,8-Diaroylated naphthalene $7 \mathrm{cc}$ or $7 \mathbf{c a}(0.1 \mathrm{mmol})$, $\mathrm{AlCl}_{3}(0.5 \mathrm{mmol}$ or $1.0 \mathrm{mmol})$, solvent (dichloromethane, 1,2-dichloroethane, or toluene; $0.25 \mathrm{ml}$ ), reflux, $30 \mathrm{~min}, \mathrm{~N}_{2}$ atmosphere; ${ }^{[\mathrm{b}]}$ Calculated on the basis of ${ }^{1} \mathrm{H}$ NMR spectra. Isolated yields are given in parentheses. [c] At r.t.

methyl-oxygen bond (Entries 7 and 8). In refluxing toluene solution, the two kinds of alkyl-oxygen bonds were thoroughly cleaved (Entry 10).

Figure 1 displays the crystal structures of aroylated 2,7-dimethoxynaphthalenes (1aa and 7aa) $[15,16]$ and aroylated 2-hydroxy-7-methoxynaphthalenes (2ba and 8ba) $[17,18]$. In 1-monoaroyl-2,7-dimethoxynaphthalene 1aa, the aroyl group non-coplanarly attaches to the naphthalene ring. On the other hand, the ketonic carbonyl moiety and hydroxy group in 1-monoaroyl-2-hydroxy-7methoxynaphthalene 2ba make a coplanar configuration with intramolecular hydrogen bond. The same type of intramolecular hydrogen bond between ketonic carbonyl moiety and hydroxy group is observed in X-ray crystal structure of 1,8-diaroyl-2-hydroxy-7-methoxynaphthalene 8ba. However, in contrast to anti-orientation of 1,8-diaroylnaphthalene 7aa, 1,8-diaroyl-2-hydroxy-7-methoxynaphthalene 8ba has syn-orientation, i.e., two aroyl groups are oriented in same directions.1-Monoaroylnaphthalene 1aa and 1,8-diaroylnaphthalene 7aa have apparently same non-coplanar alignment around the aroyl connections. However, the steric hindrance around the ketonic carbonyl group might be meaningfully different to affect the rotational capability. The aroyl groups of 1,8-diaroylnaphthalene 7aa are deviated out of the naphthalene ring plane more largely than 1-monoaroylnaphthalene 1aa. The angles between $\mathrm{C}$ (carbonyl)-C(naphthalene) bond and naphthalene plane are $13.07^{\circ}$ and $11.71^{\circ}$ for $7 \mathbf{a a}$ and $3.21^{\circ}$ for $1 \mathbf{a a}$.

The bond lengths between ketonic carbonyl group and 


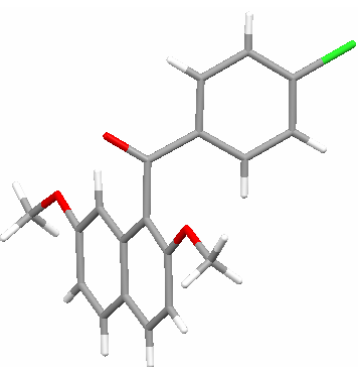

(a)

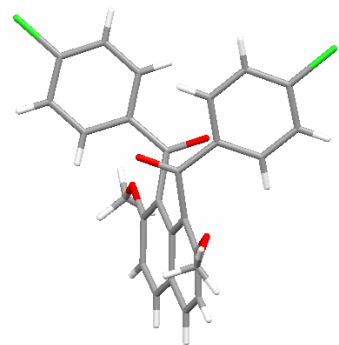

(c)

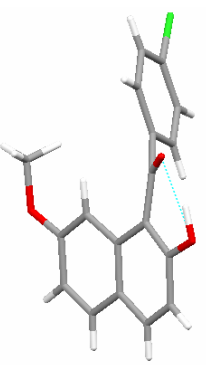

(b)

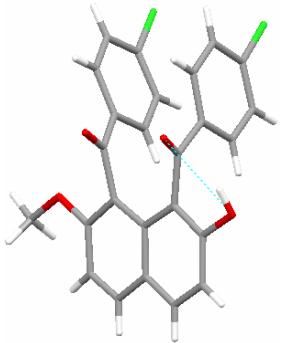

(d)
Figure 1. X-ray crystal structures of aroylnaphthalenes: (a) molecule 1aa; (b) molecule 2ba; (c) molecule 7aa; (d) molecule 8ba (For clarity, an ethanol molecule is removed from the figure).

naphthalene ring of 1,8-diaroylnaphthalene 7aa are longer than that of 1-monoaroylnaphthalene 1aa $(1.516 \AA$ and $1.520 \AA$ for 7 aa; $1.506 \AA$ for 1aa). About the 8 -aroylgroup adjacent to methoxy group in 1,8-diaroyl-2-hydroxy-7-methoxynaphthalene 8ba, the corresponding angle and bond length are $9.13^{\circ}$ and $1.509 \AA$, respecttively.

These data indicate that steric hindrance around ketonic carbonyl group increases in the order of monoaroyldimethoxy derivative 1aa $<$ diaroyl-monohydroxymonomethoxy compound 8ba $<$ diaroyl-dimethoxy compound 7aa. Furthermore, it led us to conjecture that the sterically fixed aroyl group is difficult to promote the methyl ether-cleavage. In other words, rotation ability of aroyl group presumably enables to cleave the methyl-oxygen bond by formation of the suitable arrangement of the intervening species.

\section{Conclusion}

Conclusively, the $\mathrm{AlCl}_{3}$-mediated scission behavior of alkyl-oxygen linkage of $\beta$-alkoxy groups in non-aroylated, 1-mono-, and 1,8-diaroyl-2,7-dimethoxynaphthalenes (3aa, 1aa, and 7aa) shows distinct chemospecificity. Methyl-oxygen bond cleavage of 1-monoaroyl2,7-dimethoxynaphthalene (1aa) smoothly and regioselectively proceeds at the 2-position, however, that of 1,8-diaroyl- naphthalene (7aa) is apparently deactivated like the inertness of 2,7-dimethoxynaphthalene (3aa). The single aroyl group promotes the ether cleavage of the adjacent methoxy group, whereas the two adjacent aroyl groups situated at the peri-position disturb $\mathrm{AlCl}_{3}$ mediated scission of the neighboring $\beta$-methyl ether group. Replacement of one or two methoxy groups with ethoxy ones a little blunts the chemospecificity and the regioselectivity of aroylated naphthalenes. The observed specificity in the alkyl ether-cleavage reaction affords some hitherto-unknown aspects in structures and chemical properties relationship of these congested non-coplanarly aromatic-rings-accumulated molecules.

\section{Experimental}

All reagents were of commercial quality and were used as received. Solvents were dried and purified using standard techniques.

\subsection{Measurement}

${ }^{1} \mathrm{H}$ NMR spectra were recorded on a JEOL JNM-AL300 spectrometer $(300 \mathrm{MHz})$ and a JEOL ECX400 spectrometer $(400 \mathrm{MHz})$. Chemical shifts are expressed in ppm relative to internal standard of $\mathrm{Me}_{4} \mathrm{Si}(\delta 0.00) .{ }^{13} \mathrm{C}$ NMR spectra were recorded on a JEOL JNM-AL300 spectrometer $(75 \mathrm{MHz})$ and a JEOL ECX400 spectrometer $(100 \mathrm{MHz})$. Chemical shifts are expressed in ppm relative to internal standard of $\mathrm{CDCl}_{3}(\delta 77.0)$. IR spectra were recorded on a JASCO FT/IR-4100 spectrometer. Elemental analyses were performed on a Yanaco CHN CORDER MT-5 analyzer. High-resolution FAB mass spectra were recorded on a JEOL MStation (MS700) ion trap mass spectrometer in positive ion mode.

\subsection{Typical Procedure of Methyl-OxygenBond Cleavage Reaction Mediated by $\mathrm{AlCl}_{3}$}

To a solution of 1-(4-chorobenzoyl)-2,7-dimetoxynaphthalene (1aa, $0.1 \mathrm{mmol}, 32.7 \mathrm{mg}$ ) and in dichloromethane $(0.25 \mathrm{ml}), \mathrm{AlCl}_{3}(0.5 \mathrm{mmol}, 66.7 \mathrm{mg})$ was added by portions at ambient temperature under nitrogen atmosphere. After the reaction mixture was stirred in the refluxing solution for $30 \mathrm{~min}$, it was poured into iced water $(20 \mathrm{ml})$ and the mixture was extracted with $\mathrm{CHCl}_{3}$ $(15 \mathrm{ml} \times 3)$. The combined extracts were washed with sat. $\mathrm{NaCl}$ aq. and dried over anhydrous sodium sulfate. The solvent was removed under reduced pressure to give solid. The crude product was purified by recrystallization ( $2 \mathrm{ca}$, hexane, isolated yield $75 \%$ ).

Other ether cleavage reactions were undertaken by essentially the same procedure as above.

\subsection{Synthetic Procedure of Aroylnaphthalenes}

1-(4-Chlorobenzoyl)-2,7-dimethoxynaphthalene (1aa). To a solution of 2,7-dimethoxynaphthalene $(0.200 \mathrm{mmol}$, $68.2 \mathrm{mg})$ and 4-chlorobenzoyl chloride $(0.22 \mathrm{mmol}, 38.5$ 
$\mathrm{mg})$ in dichloromethane $(0.5 \mathrm{ml}), \mathrm{AlCl}_{3}(0.22 \mathrm{mmol}, 29.3$ $\mathrm{mg}$ ) was added by portions at $0^{\circ} \mathrm{C}$ under nitrogen atmosphere. After the reaction mixture was stirred at r.t. for $3 \mathrm{~h}$, it was poured into iced water $(20 \mathrm{ml})$ and the mixture was extracted with $\mathrm{CHCl}_{3}(15 \mathrm{ml} \times 3)$. The combined extracts were washed with $2 \mathrm{M} \mathrm{NaOH}$ aq., sat. $\mathrm{NaCl}$ aq. and dried over anhydrous magnesium sulfate. The solvent was removed under reduced pressure to give powdery product. The crude product was purified by recrystallization (hexane, isolated yield $78 \%$ ).

3-(4-Chlorobenzoyl)-2,7-dimethoxynaphthalene (5aa). The title compound was prepared by treatment of a mixture of 2,7-dimethoxynaphthalene (10 mmol; $1.88 \mathrm{~g}$ ) and 4-chlorobenzoic acid (11 mmol $1.72 \mathrm{~g})$ with phosphorus pentoxide-methanesulfonic acid mixture $\left(\mathrm{P}_{2} \mathrm{O}_{5}-\mathrm{MsOH}\right.$ $[1 / 10 \mathrm{w} / \mathrm{w}] ; 10 \mathrm{ml})$ at $60^{\circ} \mathrm{C}$ for 8 hours. After the reaction mixture was stirred at $353 \mathrm{~K}$ for $8 \mathrm{~h}$, the mixture was extracted with $\mathrm{CHCl}_{3}(10 \mathrm{ml} \times 3)$. The combined extracts were washed with $2 \mathrm{M}$ aqueous $\mathrm{NaOH}$ followed by washing with brine. The organic layers thus obtained were dried over anhydrous $\mathrm{MgSO}_{4}$. The solvent was removed under reduced pressure to give cake. The crude product was purified by recrystallization (ethanol, isolated yield $56 \%$ ).

1,8-Bis(4-chlorobenzoyl)-2,7-dimethoxynaphthalene (7aa). To a solution of 2,7-dimethoxynaphthalene $(0.200$ $\mathrm{mmol}, 68.2 \mathrm{mg})$ and 4-chlorobenzoyl chloride (0.66 $\mathrm{mmol}, 116 \mathrm{mg})$ in dichloromethane $(0.5 \mathrm{ml}), \mathrm{TiCl}_{4}(1.8$ $\mathrm{mmol}, 341 \mathrm{mg}$ ) was added by portions at r.t. under nitrogen atmosphere. After the reaction mixture was stirred at r.t. for $3 \mathrm{~h}$, it was poured into iced water $(20 \mathrm{ml})$ and the mixture was extracted with $\mathrm{CHCl}_{3}(15 \mathrm{ml} \times 3)$. The combined extracts were washed with $2 \mathrm{M} \mathrm{NaOH}$ aq., sat. $\mathrm{NaCl}$ aq. and dried over anhydrous magnesium sulfate. The solvent was removed under reduced pressure to give powdery product. The crude product was purified by recrystallization (ethanol, isolated yield $88 \%$ ).

1,8-Bis(4-chlorobenzoyl)-2,7-diethoxynaphthalene (7cc). To a solution of $\mathrm{TiCl}_{4}(180 \mathrm{mmol}, 34.2 \mathrm{~g})$ and 4chlorobenzoyl chloride $(60 \mathrm{mmol}, 10.5 \mathrm{~g})$ in dichloromethane $(25 \mathrm{ml})$, 2.7-diethoxynaphthalene/dichloromethane $(20 \mathrm{mmol}, 4.33 \mathrm{~g} / 25 \mathrm{ml})$ was added by portions at r.t. under nitrogen atmosphere. After the reaction mixture was stirred at r.t. for $3 \mathrm{~h}$, it was poured into iced water $(200 \mathrm{ml})$ and the mixture was extracted with $\mathrm{CHCl}_{3}$ $(40 \mathrm{ml} \times 3)$. The combined extracts were washed with 2 $\mathrm{M} \mathrm{NaOH}$ aq., sat. $\mathrm{NaCl}$ aq. and dried over anhydrous magnesium sulfate. The solvent was removed under reduced pressure to give powdery pale white product $(94 \%$ yield). The crude product was purified by recrystallization (chloroform/ethanol, isolated yield 62\%).

1,8-Bis(4-chlorobenzoyl)-2-ethoxy-7-methoxynapht halene (7ca). To a solution of 1-(4-chlorobenzoyl)-2ethoxy-7-methoxynaphthalene $(0.200 \mathrm{mmol}, 68.2 \mathrm{mg})$ and 4-chlorobenzoyl chloride $(0.44 \mathrm{mmol}, 77.0 \mathrm{mg})$ in dichloromethane $(0.5 \mathrm{ml}), \mathrm{TiCl}_{4}(1.32 \mathrm{mmol}, 248 \mathrm{mg})$ was added by portions at r.t. under nitrogen atmosphere. After the reaction mixture was stirred at r.t. for $3 \mathrm{~h}$, it was poured into iced water $(20 \mathrm{ml})$ and the mixture was extracted with $\mathrm{CHCl}_{3}(15 \mathrm{ml} \times 3)$. The combined extracts were washed with $2 \mathrm{M} \mathrm{NaOH}$ aq., sat. $\mathrm{NaCl}$ aq. and dried over anhydrous magnesium sulfate. The solvent was removed under reduced pressure to give powdery product. The crude product was purified by silicagel column chromatography (hexane : $\mathrm{AcOEt}=1: 1$, isolated yield $87 \%$ ).

\subsection{Identification of the Products}

1-(4-Chlorobenzoyl)-2,7-dimethoxynaphthalene (1aa). Colorless needle (hexane), Mp $121.5^{\circ} \mathrm{C}-122^{\circ} \mathrm{C}$; IR (KBr): $1667,1628,1586,1512 \mathrm{~cm}^{-1} ;{ }^{1} \mathrm{H}$ NMR $\delta(300$ $\left.\mathrm{MHz}, \mathrm{CDCl}_{3}\right): 3.73(3 \mathrm{H}, \mathrm{s}), 3.79(3 \mathrm{H}, \mathrm{s}), 6.78(1 \mathrm{H}, \mathrm{d}, J=$ $2.4 \mathrm{~Hz}), 7.02(1 \mathrm{H}, \mathrm{dd}, J=2.4,9.0 \mathrm{~Hz}), 7.16(1 \mathrm{H}, \mathrm{d}, J=$ $9.0 \mathrm{~Hz}), 7.39(2 \mathrm{H}, \mathrm{d}, J=8.4 \mathrm{~Hz}), 7.72(1 \mathrm{H}, \mathrm{d}, J=9.0$ $\mathrm{Hz}), 7.78(2 \mathrm{H}, \mathrm{d}, J=8.4 \mathrm{~Hz}), 7.87(1 \mathrm{H}, \mathrm{d}, J=9.0 \mathrm{~Hz})$ ppm; ${ }^{13} \mathrm{C}$ NMR $\delta\left(75 \mathrm{MHz}, \mathrm{CDCl}_{3}\right): 55.168,56.239$, $101.88,110.05,117.15,121.06,124.34,128.86,129.72$, 130.87, 131.28, 132.94, 136.45, 139.71, 155.02, 158.96, $196.81 \mathrm{ppm}$; Calcd for $\mathrm{C}_{19} \mathrm{H}_{15} \mathrm{O}_{3} \mathrm{Cl}: \mathrm{C}, 69.83 \%$; $\mathrm{H}$, 4.63\%; Found: C, $69.61 \%$; H, 4.74\%.

1-(4-Chlorobenzoyl)-2-hydroxy-7-methoxynaphthal ene (2ba). Yellow platelet (hexane), $\mathrm{Mp} 118^{\circ} \mathrm{C}-118.5^{\circ} \mathrm{C}$; IR (KBr): 3434, 1623, 1583, 1513, 1214, $843 \mathrm{~cm}^{-1} ;{ }^{1} \mathrm{H}$ NMR $\delta\left(300 \mathrm{MHz}, \mathrm{CDCl}_{3}\right): 3.37(\mathrm{~s}, 3 \mathrm{H}), 6.58(\mathrm{~d}, 1 \mathrm{H}, J=$ $2.4 \mathrm{~Hz}), 6.91(\mathrm{dd}, 1 \mathrm{H}, J=2.4,9.0 \mathrm{~Hz}), 7.07(\mathrm{~d}, 1 \mathrm{H}, J=$ $9.0 \mathrm{~Hz}), 7.40(\mathrm{~d}, 2 \mathrm{H}, J=8.7 \mathrm{~Hz}), 7.58(\mathrm{~d}, 2 \mathrm{H}, J=8.7$ $\mathrm{Hz}), 7.63(\mathrm{~d}, 1 \mathrm{H}, J=9.0 \mathrm{~Hz}), 7.85(\mathrm{~d}, 1 \mathrm{H}, J=9.0 \mathrm{~Hz})$, 11.35 (s, 1H) ppm; ${ }^{13} \mathrm{C}$ NMR $\delta\left(75 \mathrm{MHz}, \mathrm{CDCl}_{3}\right): 54.5$, $106.5,113.4,115.8,116.4,123.7,128.9,130.2,130.7$, $133.8,136.5,138.7,138.8,158.2,162.6,199.1 \mathrm{ppm}$; Anal. Calcd for $\mathrm{C}_{18} \mathrm{H}_{13} \mathrm{ClO}_{3}$ : C 69.13, H 4.19. Found: C 69.11, H 4.09.

1-(4-Chlorobenzoyl)-2,7-dihydroxynaphthalene (2bb). Yellow oil; IR (KBr): 3398, 1653, 1625, 1586, 1515, 1240, $1215 \mathrm{~cm}^{-1}$; $1 \mathrm{H}$ NMR $\delta\left(400 \mathrm{MHz}, \mathrm{CDCl}_{3}\right): 5.18$ $(1 \mathrm{H}, \mathrm{s}), 6.61(1 \mathrm{H}, \mathrm{d}, J=2.2 \mathrm{~Hz}), 6.89(1 \mathrm{H}, \mathrm{dd}, J=2.2$, $8.6 \mathrm{~Hz}), 7.07(1 \mathrm{H}, \mathrm{d}, J=8.8 \mathrm{~Hz}), 7.39(2 \mathrm{H}, \mathrm{d}, J=8.2$ $\mathrm{Hz}), 7.60(2 \mathrm{H}, \mathrm{d}, J=8.2 \mathrm{~Hz}), 7.66(1 \mathrm{H}, \mathrm{d}, J=8.8 \mathrm{~Hz})$, $7.85(1 \mathrm{H}, \mathrm{d}, J=8.8 \mathrm{~Hz}), 11.14(1 \mathrm{H}, \mathrm{s}) \mathrm{ppm} ;{ }^{13} \mathrm{C}$ NMR $\delta$ $\left(100 \mathrm{MHz}, \mathrm{CDCl}_{3}\right): 109.62,113.16,115.07,116.55$, $123.75,128.95,130.76,130.97,133.92,136.48,138.26$, 139.07, 154.53, 162.33, 198.71 ppm; HRMS (FAB; $m$-nitrobenzyl alcohol [m-NBA]) m/z: $[\mathrm{M}+\mathrm{H}]^{+}$; Calcd for $\mathrm{C}_{17} \mathrm{H}_{12} \mathrm{O}_{3} \mathrm{Cl}$ : 299.0475; Found: 299.0502 .

3-(4-Chlorobenzoyl)-2,7-dimethoxynaphthalene (5aa). Yellow needle (EtOH), Mp $152^{\circ} \mathrm{C}$; IR (KBr): 1657, 1622, $1588,1503 \mathrm{~cm}^{-1} ;{ }^{1} \mathrm{H}$ NMR $\delta\left(300 \mathrm{MHz}, \mathrm{CDCl}_{3}\right): 3.82$ $(3 \mathrm{H}, \mathrm{s}), 3.94(3 \mathrm{H}, \mathrm{s}), 7.05(1 \mathrm{H}, \mathrm{dd}, J=2.4,8.9 \mathrm{~Hz}), 7.10$ 
$(1 \mathrm{H}, \mathrm{d}, J=2.4 \mathrm{~Hz}), 7.13(1 \mathrm{H}, \mathrm{s}), 7.40(2 \mathrm{H}, \mathrm{d}, J=8.7 \mathrm{~Hz})$, $7.69(1 \mathrm{H}, \mathrm{d}, J=8.7 \mathrm{~Hz}), 7.77(2 \mathrm{H}, \mathrm{d}, J=8.7 \mathrm{~Hz}), 7.79$ $(1 \mathrm{H}, \mathrm{s}) \mathrm{ppm} ;{ }^{13} \mathrm{C} \mathrm{NMR} \delta\left(75 \mathrm{MHz}, \mathrm{CDCl}_{3}\right): 55.349$, 55.522, 105.03, 105.44, 117.17, 123.20, 127.41, 128.50, 130.08, 130.24, 131.22, 137.28, 138.83, 139.20, 155.67, 159.47, 194.81 ppm; Calcd for $\mathrm{C}_{19} \mathrm{H}_{15} \mathrm{O}_{3} \mathrm{Cl}$ : C, 69.83\%; H, 4.63\%. Found: C, 69.75\%; H, 4.83\%.

3-(4-Chlorobenzoyl)-2-hydroxy-7-methoxynaphthal ene (6ba). Yellow needle (AcOEt + hexane); Mp $177^{\circ} \mathrm{C}$; IR (KBr): 3470, 1643, 1594, 1561, $1511 \mathrm{~cm}^{-1}$; ${ }^{1} \mathrm{H}$ NMR $\delta\left(300 \mathrm{MHz} \mathrm{CDCl}_{3}\right): 3.93(3 \mathrm{H}, \mathrm{s}), 6.94(1 \mathrm{H}, \mathrm{br}), 6.96$ $(1 \mathrm{H}, \mathrm{d}, J=8.4,2.4 \mathrm{~Hz}), 7.23(1 \mathrm{H}, \mathrm{s}), 7.52(2 \mathrm{H}, \mathrm{d}, J=8.9$ $\mathrm{Hz}), 7.57(1 \mathrm{H}, \mathrm{d}, J=8.4 \mathrm{~Hz}), 7.69(2 \mathrm{H}, \mathrm{d}, J=9.0 \mathrm{~Hz})$, $7.99(1 \mathrm{H}, \mathrm{s}), 11.26(1 \mathrm{H}, \mathrm{s}) \mathrm{ppm} ;{ }^{13} \mathrm{C} \mathrm{NMR} \delta(75 \mathrm{MHz}$, $\left.\mathrm{CDCl}_{3}\right): 55.383,103.68,111.25,117.80,118.50,122.24$, 128.72, 130.78, 131.24, 136.09, 136.36, 138.43, 140.07, 158.17, 161.09, 200.01 ppm; HRMS (FAB; $m$-NBA) $m / z$ : $[\mathrm{M}+\mathrm{H}]^{+}$; Calcd for $\mathrm{C}_{18} \mathrm{H}_{14} \mathrm{O}_{3} \mathrm{Cl}$ : 313.0631. Found: 313.0624.

3-(4-Chlorobenzoyl)-2,7-dihydroxynaphthalene (6bb). Yellow powder (AcOEt + hexane), $\mathrm{Mp} 148^{\circ} \mathrm{C}-148.5^{\circ} \mathrm{C}$; IR (KBr): 3422, 1648, 1593, 1561, $1524 \mathrm{~cm}^{-1} ;{ }^{1} \mathrm{H}$ NMR $\delta\left(400 \mathrm{MHz}, \mathrm{CDCl}_{3}\right): 6.01(1 \mathrm{H}, \mathrm{s}), 6.94(1 \mathrm{H}, \mathrm{dd}, J=8.6$, $2.4 \mathrm{~Hz}), 6.99(1 \mathrm{H}, \mathrm{d}, J=2.4 \mathrm{~Hz}), 7.17(1 \mathrm{H}, \mathrm{s}), 7.53(2 \mathrm{H}$, d, $J=8.4 \mathrm{~Hz}), 7.63(1 \mathrm{H}, \mathrm{d}, J=9.2 \mathrm{~Hz}), 7.69(2 \mathrm{H}, \mathrm{d}, J=$ $8.8 \mathrm{~Hz}), 8.02(1 \mathrm{H}, \mathrm{s}), 11.22(1 \mathrm{H}, \mathrm{s}) \mathrm{ppm} ;{ }^{13} \mathrm{C} \mathrm{NMR} \delta$ $\left(100 \mathrm{MHz}, \mathrm{CDCl}_{3}\right): 107.64,110.70,116.84,118.76$, $122.33,128.79,130.81,132.00,136.38,136.50,138.55$, 140.02, 157.43, 158.03, 200.13 ppm; HRMS (FAB; $m$-NBA) $m / z$ : $[\mathrm{M}+\mathrm{H}]^{+}$; Calcd for $\mathrm{C}_{17} \mathrm{H}_{12} \mathrm{O}_{3} \mathrm{Cl}$ : 299.0475; Found: 299.0501 .

1,8-Bis(4-chlorobenzoyl)-2,7-dimethoxynaphthalene (7aa). Yellow needle $(\mathrm{EtOH}+\mathrm{AcOEt}), \mathrm{Mp} 216^{\circ} \mathrm{C}$ $217^{\circ} \mathrm{C}$; IR (KBr): $1665,1611,1588,1512 \mathrm{~cm}^{-1}$; ${ }^{1} \mathrm{H}$ NMR $\delta\left(300 \mathrm{MHz}, \mathrm{CDCl}_{3}\right): 3.70(6 \mathrm{H}, \mathrm{s}), 7.21(2 \mathrm{H}, \mathrm{d}, J=9.0$ $\mathrm{Hz}), 7.33(4 \mathrm{H}, \mathrm{d}, J=8.6 \mathrm{~Hz}), 7.64(4 \mathrm{H}, \mathrm{d}, J=8.6 \mathrm{~Hz})$, $7.96(2 \mathrm{H}, \mathrm{d}, J=9.0 \mathrm{~Hz}) \mathrm{ppm} ;{ }^{13} \mathrm{C} \mathrm{NMR} \delta(75 \mathrm{MHz}$, $\mathrm{CDCl}_{3}$ ): 56.297, 111.07, 120.57, 125.45, 128.37, 129.90, 130.40, 132.43, 137.07, 138.99, 156.39, 195.95 ppm; Calcd for $\mathrm{C}_{26} \mathrm{H}_{18} \mathrm{O}_{4} \mathrm{Cl}_{2}$ : C, 67.11\%; H, 3.90\%. Found: $\mathrm{C}$, $67.10 \%$; H, 4.09\%.

1,8-Bis(4-chlorobenzoyl)-2-hydroxy-7-methoxynaphthalene (8ba). Yellow platelet $(\mathrm{EtOH}), \mathrm{Mp} 232.5^{\circ} \mathrm{C}$ $233.5^{\circ} \mathrm{C}$; IR (KBr): 1643, 1612, 1587, 1510, 1278, 1089, $831 \mathrm{~cm}^{-1}$; ${ }^{1} \mathrm{H}$ NMR $\delta\left(300 \mathrm{MHz}, \mathrm{CDCl}_{3}\right): 3.60(\mathrm{~s}, 3 \mathrm{H})$, $6.91(\mathrm{~d}, J=8.7 \mathrm{~Hz}, 2 \mathrm{H}), 7.20-7.10(\mathrm{~m}, 6 \mathrm{H}), 7.33(\mathrm{~d}, J=$ $8.7 \mathrm{~Hz}, 2 \mathrm{H}), 7.94-7.86(\mathrm{~m}, 2 \mathrm{H}), 9.34(\mathrm{~s}, 1 \mathrm{H}) \mathrm{ppm} ;{ }^{13} \mathrm{C}$ $\mathrm{NMR} \delta\left(75 \mathrm{MHz}, \mathrm{CDCl}_{3}\right): 56.0,110.6,117.3,121.3$, $124.6,127.7,128.5,130.5,131.9,132.6,133.7,135.0$, $136.3,136.8,138.4,139.7,157.6,159.5,195.1,196.8$ ppm; HRMS (FAB; $m$-NBA) m/z: $[\mathrm{M}+\mathrm{H}]^{+}$; calcd for $\mathrm{C}_{25} \mathrm{H}_{17} \mathrm{O}_{4} \mathrm{Cl}_{2}$, 451.0504; found, 451.0520. Anal. Calcd for $\mathrm{C}_{25} \mathrm{H}_{16} \mathrm{O}_{4} \mathrm{Cl}_{2}$ : C 66.53, H 3.57. Found: C 66.31, H 3.76.

1,8-Bis(4-chlorobenzoyl)-2,7-dihydroxynaphthalene (8bb). Yellow powder (AcOEt), Mp $302.2^{\circ} \mathrm{C}-307.4^{\circ} \mathrm{C}$; IR (KBr); 3160 (O-H), $1643(\mathrm{C}=\mathrm{O}), 1587$ (Ar), 1511 (Ar) $\mathrm{cm}^{-1} ;{ }^{1} \mathrm{H}$ NMR $\delta\left(300 \mathrm{MHz}, \mathrm{CDCl}_{3}\right): 7.11-7.15(4 \mathrm{H}$, broad), $7.14(2 \mathrm{H}, J=8.7 \mathrm{~Hz}), 7.25-7.28(4 \mathrm{H}, \mathrm{m}), 7.93$ $(2 \mathrm{H}, \mathrm{d}, J=9.0 \mathrm{~Hz}), 11.13(2 \mathrm{H}, \mathrm{s}) \mathrm{ppm} .{ }^{1} \mathrm{H}$ NMR $\delta(300$ MHz, DMSO): 7.09 (2H, d, $J=8.7 \mathrm{~Hz}), 7.49$ (4H, d, $J=$ $8.4 \mathrm{~Hz}), 7.61(4 \mathrm{H}, \mathrm{d}, J=8.7 \mathrm{~Hz}), 7.93(2 \mathrm{H}, \mathrm{d}, J=9.0$ $\mathrm{Hz}), 10.12(2 \mathrm{H}, \mathrm{s}) \mathrm{ppm} ;{ }^{13} \mathrm{C}$ NMR $\delta(75 \mathrm{MHz}, \mathrm{DMSO})$ : $115.44,117.61,123.76,128.79,131.19,132.73,137.65$, 137.96, 155.04, 196.56 ppm; HRMS (FAB; $m$-NBA) m/z: $[\mathrm{M}+\mathrm{H}]^{+}$, calcd for $\mathrm{C}_{24} \mathrm{H}_{14} \mathrm{Cl}_{2} \mathrm{O}_{4} \mathrm{Na}$, 459.0167; found, 459.0132 .

1-(4-Chlorobenzoyl)-2,7-diethoxynaphthalene (1cc). Colorless needle (hexane), $\mathrm{Mp} 124^{\circ} \mathrm{C}-125^{\circ} \mathrm{C}$; IR (KBr): $1660,1625,1582,1514,1242,1216 \mathrm{~cm}^{-1} ;{ }^{1} \mathrm{H}$ NMR $\delta$ $\left(400 \mathrm{MHz}, \mathrm{CDCl}_{3}\right): 1.09(3 \mathrm{H}, \mathrm{t}, J=6.8 \mathrm{~Hz}), 1.36(3 \mathrm{H}, \mathrm{t}$, $J=7.2 \mathrm{~Hz}), 3.96(2 \mathrm{H}, \mathrm{q}, J=10,14 \mathrm{~Hz}), 4.04(2 \mathrm{H}, \mathrm{q}, J=$ $10,14 \mathrm{~Hz}), 6.83(1 \mathrm{H}, \mathrm{d}, J=2.4 \mathrm{~Hz}), 7.01(1 \mathrm{H}, \mathrm{dd}, J=$ 2.4, $9.2 \mathrm{~Hz}), 7.10(1 \mathrm{H}, \mathrm{d}, J=8.8 \mathrm{~Hz}), 7.38(2 \mathrm{H}, \mathrm{d}, \mathrm{J}=8.6$ $\mathrm{Hz}), 7.70(1 \mathrm{H}, \mathrm{d}, J=8.8 \mathrm{~Hz}), 7.76(2 \mathrm{H}, \mathrm{d}, \mathrm{J}=8.6 \mathrm{~Hz})$, $7.83(1 \mathrm{H}, \mathrm{d}, J=9.2 \mathrm{~Hz}) \mathrm{ppm} ;{ }^{13} \mathrm{C} \mathrm{NMR} \delta(100 \mathrm{MHz}$, $\left.\mathrm{CDCl}_{3}\right): 14.577,14.596,63.394,64.805,102.78,111.20$, $117.33,121.41,124.32,128.72,129.65,130.72,131.30$, 133.12, 136.99, 139.40, 154.63, 158.35, 196.97 ppm; HRMS (FAB; $m$-NBA) m/z: $[\mathrm{M}+\mathrm{H}]^{+}$; Calcd for $\mathrm{C}_{21} \mathrm{H}_{20} \mathrm{O}_{3} \mathrm{Cl}$ : 355.1101; Found:355.1061.

1-(4-Chlorobenzoyl)-7-ethoxy-2-hydroxynaphthale ne (2cb). Glassy yellow solid (oil); IR (KBr): 3239, 1656, $1619,1594,1571,1513,1203 \mathrm{~cm}^{-1}$; ${ }^{1} \mathrm{H}$ NMR $\delta(400$ $\left.\mathrm{MHz} \mathrm{CDCl}_{3}\right): 1.22(3 \mathrm{H}, \mathrm{t}, J=7.0 \mathrm{~Hz}), 3.52(2 \mathrm{H}, \mathrm{q}, J=$ $10,14 \mathrm{~Hz}), 6.55(1 \mathrm{H}, \mathrm{d}, J=2.5 \mathrm{~Hz}), 6.90(1 \mathrm{H}, \mathrm{dd}, J=$ $2.5,8.8 \mathrm{~Hz}), 7.05(1 \mathrm{H}, \mathrm{d}, J=8.8 \mathrm{~Hz}), 7.40(2 \mathrm{H}, \mathrm{d}, J=$ $8.4 \mathrm{~Hz}), 7.57(2 \mathrm{H}, \mathrm{d}, J=8.4 \mathrm{~Hz}), 7.61(1 \mathrm{H}, \mathrm{d}, J=9.2$ $\mathrm{Hz}), 7.83(1 \mathrm{H}, \mathrm{d}, J=9.2 \mathrm{~Hz}), 11.29(1 \mathrm{H}, \mathrm{s}) \mathrm{ppm} ;{ }^{13} \mathrm{C}$ NMR $\delta\left(100 \mathrm{MHz}, \mathrm{CDCl}_{3}\right): 14.510,62.898,107.08$, $113.42,116.25,116.30,123.60,128.93,130.15,130.65$, $133.86,136.52,138.62,138.78,138.80,157.61,162.48$, 199.07 ppm; HRMS (FAB; $m$-NBA) $m / z$ : $[\mathrm{M}+\mathrm{H}]^{+}$; Calcd for $\mathrm{C}_{19} \mathrm{H}_{16} \mathrm{O}_{3} \mathrm{Cl}$ : 327.0788; Found: 327.0784 .

3-(4-Chlorobenzoyl)-2,7-diethoxynaphthalene (5cc). Yellow oil (AcOEt+hexane); IR (KBr): 1663, 1626, 1585, 1504, $1211 \mathrm{~cm}^{-1} ;{ }^{1} \mathrm{H}$ NMR $\delta\left(400 \mathrm{MHz}, \mathrm{CDCl}_{3}\right): 1.14$ $(3 \mathrm{H}, \mathrm{t}, J=6.8 \mathrm{~Hz}), 1.49(3 \mathrm{H}, \mathrm{t}, J=6.8 \mathrm{~Hz}), 4.04(2 \mathrm{H}, \mathrm{q}$, $J=10,14 \mathrm{~Hz}), 4.16(2 \mathrm{H}, \mathrm{q}, J=10,14 \mathrm{~Hz}), 7.04(1 \mathrm{H}, \mathrm{dd}$, $J=2.4,8.8 \mathrm{~Hz}), 7.05(1 \mathrm{H}, \mathrm{br}), 7.07(1 \mathrm{H}, \mathrm{s}), 7.40$ (2H, d, $J=8.4 \mathrm{~Hz}), 7.69(1 \mathrm{H}, \mathrm{d}, J=8.8 \mathrm{~Hz}), 7.74(2 \mathrm{H}, \mathrm{d}, J=8.4$ $\mathrm{Hz}), 7.83(1 \mathrm{H}, \mathrm{s}) \mathrm{ppm} ;{ }^{13} \mathrm{C} \mathrm{NMR} \delta\left(100 \mathrm{MHz}, \mathrm{CDCl}_{3}\right)$ : $14.234,14.777,63.528,63.804,105.65,106.06,106.08$, $117.35,123.20,127.61,128.31,130.14,130.36,130.99$, 137.06, 137.46, 138.83, 154.95, 158.78, 195.18 ppm; HRMS (FAB; $m$-NBA) $m / z:[\mathrm{M}+\mathrm{H}]^{+}$; Calcd for $\mathrm{C}_{21} \mathrm{H}_{20} \mathrm{O}_{3} \mathrm{Cl}$ : 355.1101; Found: 355.1112 .

3-(4-Chlorobenzoyl)-7-ethoxy-2-hydroxynaphthale ne (6cb). Yellow needle, $\left(\mathrm{CHCl}_{3}+\right.$ hexane); $\mathrm{Mp} 151^{\circ} \mathrm{C}$; 
IR (KBr): 3448, 1638, 1593, 1560, 1509, 1236, 1209 $\mathrm{cm}^{-1}$; ${ }^{1} \mathrm{H}$ NMR $\delta\left(300 \mathrm{MHz}, \mathrm{CDCl}_{3}\right): 1.49(3 \mathrm{H}, \mathrm{t}, J=7.0$ $\mathrm{Hz}), 4.17$ (2H, q, $J=11,14 \mathrm{~Hz}), 6.95(1 \mathrm{H}, \mathrm{brs}), 6.95(1 \mathrm{H}$, $\mathrm{dd}, J=8.8,2.4 \mathrm{~Hz}), 7.22(1 \mathrm{H}, \mathrm{s}), 7.52(2 \mathrm{H}, \mathrm{d}, J=8.4$ $\mathrm{Hz}), 7.59(1 \mathrm{H}, \mathrm{d}, J=8.7 \mathrm{~Hz}), 7.69(2 \mathrm{H}, \mathrm{d}, J=8.4 \mathrm{~Hz})$, $8.00(1 \mathrm{H}, \mathrm{s}), 11.26(1 \mathrm{H}, \mathrm{s}) \mathrm{ppm} ;{ }^{13} \mathrm{C} \mathrm{NMR} \delta(400 \mathrm{MHz}$, $\left.\mathrm{CDCl}_{3}\right): 14.663,63.699,104.40,111.22,118.09,118.52$, $122.24,128.77,128.92,130.81,131.27,136.15,138.46$, 140.21, 158.19, 160.53, 200.05 ppm; HRMS (FAB; $m$-NBA) $m / z:[\mathrm{M}+\mathrm{H}]^{+}$; Calcd for $\mathrm{C} 19 \mathrm{H} 16 \mathrm{O} 3 \mathrm{Cl}$ : 327.0788. Found: 327.0784 .

1,8-Bis(4-chlorobenzoyl)-2,7-diethoxynaphthalene (7cc). Colorless needle (Chloroform/EtOH), Mp $214.1^{\circ} \mathrm{C}$ - 216.2 ${ }^{\circ} \mathrm{C}$; IR (KBr): $1660(\mathrm{C}=\mathrm{O}), 1610(\mathrm{Ar}), 1510$ (Ar), 1274 (O-Et) $\mathrm{cm}^{-1} ;{ }^{1} \mathrm{H}$ NMR $\delta\left(300 \mathrm{MHz}, \mathrm{CDCl}_{3}\right): 0.96$ $(6 \mathrm{H}, \mathrm{t}, J=6.9 \mathrm{~Hz}), 3.97(4 \mathrm{H}, \mathrm{q}, J=7.2 \mathrm{~Hz}), 7.15(2 \mathrm{H}, \mathrm{d}$, $J=9.0 \mathrm{~Hz}), 7.34(4 \mathrm{H}, \mathrm{d}, J=8.4 \mathrm{~Hz}), 7.67(4 \mathrm{H}, \mathrm{d}, J=8.4$ $\mathrm{Hz}), 7.92(2 \mathrm{H}, \mathrm{d}, J=8.7 \mathrm{~Hz}) \mathrm{ppm} ;{ }^{13} \mathrm{C} \mathrm{NMR} \delta(100 \mathrm{MHz}$, $\left.\mathrm{CDCl}_{3}\right) ; 14.52,64.48,112.19,121.06,125.53,128.38$, $130.45,132.52,137.78,138.78,156.10,196.63$ ppm.; HRMS (FAB; $m$-NBA) m/z: $[\mathrm{M}+\mathrm{H}]^{+}$; calcd for $\mathrm{C}_{28} \mathrm{H}_{23} \mathrm{Cl}_{2} \mathrm{O}_{4}$, 493.0973; found, 493.0958.

1,8-Bis(4-chlorobenzoyl)-2-ethoxy-7-methoxynapht halene (7ca). Pale yellow needle (silicagel column, hexane: $\mathrm{AcOEt}=1: 1), \mathrm{Mp} 209.3^{\circ} \mathrm{C}-210.1^{\circ} \mathrm{C}$; IR $(\mathrm{KBr})$ : $1663,1609,1587,1510,1267,1047,838 \mathrm{~cm}^{-1}$; ${ }^{1} \mathrm{H}$ NMR $\delta\left(300 \mathrm{MHz}, \mathrm{CDCl}_{3}\right): 0.96(\mathrm{t}, J=7.0 \mathrm{~Hz}, 3 \mathrm{H}), 3.70(\mathrm{~s}$, $3 \mathrm{H}), 3.97$ (q, $J=10,14 \mathrm{~Hz}, 2 \mathrm{H}), 7.21-7.14(\mathrm{~m}, 2 \mathrm{H})$, 7.97 - $7.91(\mathrm{~m}, 2 \mathrm{H}), 7.33(\mathrm{~d}, J=8.7 \mathrm{~Hz}, 4 \mathrm{H}), 7.67$ - 7.63 $(\mathrm{m}, 4 \mathrm{H}) \mathrm{ppm} ;{ }^{13} \mathrm{C}$ NMR $\delta\left(75 \mathrm{MHz}, \mathrm{CDCl}_{3}\right): 14.4,56.4$, $65.0,111.2,112.3,121.1,121.3,125.6,128.3,128.4$, $130.2,130.4,130.5,132.3,132.4,137.3,137.7,138.8$, 139.0, 156.0, 156.5, 196.0, 196.1 ppm; HRMS (FAB; $m$-NBA) $m / z$ : $[\mathrm{M}+\mathrm{H}]^{+}$; calcd for $\mathrm{C}_{27} \mathrm{H}_{21} \mathrm{O}_{4} \mathrm{Cl}_{2}, 479.0817$; found, 479.0822. Anal. Calcd for $\mathrm{C}_{27} \mathrm{H}_{20} \mathrm{O}_{4} \mathrm{Cl}_{2}$ : C, 67.65; H, 4.21. Found: C, 67.45; H, 4.10.

1,8-Bis(4-chlorobenzoyl)-2-ethoxy-7-hydroxynapht halene (8bc). Yellow powder (silicagel column, AcOEt), Mp $200.3^{\circ} \mathrm{C}-203.9^{\circ} \mathrm{C}$; IR (KBr): 3378, 1644, 1611, 1589, 1567, 1510, 1208, 1225, 1281, 1090, $803 \mathrm{~cm}^{-1} ;{ }^{1} \mathrm{H}$ NMR $\delta\left(400 \mathrm{MHz}, \mathrm{CDCl}_{3}\right): 0.85(3 \mathrm{H}, \mathrm{t}, J=6.8 \mathrm{~Hz}), 3.89$ $(2 \mathrm{H}, \mathrm{q}, J=10,14 \mathrm{~Hz}), 6.88(2 \mathrm{H}, \mathrm{d}, J=8.0 \mathrm{~Hz}), 7.07(1 \mathrm{H}$, $\mathrm{d}, J=8.8 \mathrm{~Hz}), 7.09-7.16(3 \mathrm{H}, \mathrm{m}), 7.18(2 \mathrm{H}, \mathrm{d}, J=8.4$ $\mathrm{Hz}), 7.31(2 \mathrm{H}, \mathrm{d}, J=8.4 \mathrm{~Hz}), 7.88(1 \mathrm{H}, \mathrm{d}, J=8.4 \mathrm{~Hz})$, $7.90(1 \mathrm{H}, \mathrm{d}, J=8.8 \mathrm{~Hz}), 9.53(1 \mathrm{H}, \mathrm{s}) \mathrm{ppm} ;{ }^{13} \mathrm{C} \mathrm{NMR} \delta$ $\left(100 \mathrm{MHz}, \mathrm{CDCl}_{3}\right): 14.043,69.491,111.33,113.98$, $117.07,121.13,124.39,127.46,128.42,130.31,131.98$, $132.68,133.70,135.09,136.54,136.73,138.13,139.58$, 157.08, 159.57, 195.59, 197.12 ppm; HRMS (FAB; $m$-NBA) m/z: $[\mathrm{M}+\mathrm{H}]^{+}$, calcd for $\mathrm{C}_{26} \mathrm{H}_{19} \mathrm{Cl}_{2} \mathrm{O}_{4}, 465.0660$; found 465.0629 .

\section{Acknowledgements}

This work was partially supported by the Shorai Founda- tion for Science and Technology and the Iron and Steel Institute of Japan (ISIJ) Research Promotion Grant.

\section{REFERENCES}

[1] Z. Furen, S. Haibin and Z. Guofu, "Synthesis and Catalytic Activity of Group 5 Metal Amides with Chiral Biaryldiamine-Based Ligands," Dalton Transactions, Vol. 40, No. 7, 2011, pp. 1547-1566. doi:10.1039/c0dt01229g

[2] J-P. Genet, “Asymmetric Catalytic Hydrogenation. Design of New Ru Catalysts and Chiral Ligands: from Laboratory to Industrial Applications," Accounts of Chemical Research, Vol. 36, No. 12, 2003, pp. 908-918. doi:10.1021/ar020152u

[3] O. Lucchi, "High Symmetry Chiral Auxiliaries Containing Heteroatoms," Pure and Applied Chemistry, Vol. 68, No. 4, 1996, pp. 945-950. doi:10.1351/pac199668040945

[4] K. Maruoka, "Assymetric Phase Transfer Catalysis," Wiley-VCH, Weinheim, 2008. doi:10.1002/9783527622627

[5] A. Okamoto and N. Yonezawa,"Reversible $\mathrm{ArS}_{\mathrm{E}}$ Aroyla tion of Naphthalene Derivatives," Chemistry Letters, Vol. 38, No. 9, 2009, pp. 914-915. doi:10.1246/c1.2009.914

[6] A. Okamoto, R. Mitsui, H. Oike and N. Yonezawa, "Lewis Acid-Mediated $\mathrm{ArS}_{\mathrm{E}}$ Aroylation of Naphthalene Derivative: Distinct Second Aroylation Behavior of Naphthyl Ketone," Chemistry Letters, Vol. 40, No. 11, 2011, pp. 1283-1284. doi:10.1246/cl.2011.1283

[7] K. Nakaema, S. Watanabe, A. Okamoto, K. Noguchiand and N. Yonezawa, "1,8-Dibenzoyl-2,7-dimethoxynaphthalene," Acta Crystallographica Section E, Vol. 64, No. 5, 2008, p. 807. doi:10.1107/S1600536808007009

[8] K. Sasagawa, T. Muto, A. Okamoto, H. Oikeand and N. Yonezawa, "[8-(4-Butoxybenzoyl)-2,7-dimethoxynaphthalen-1-yl](4-butoxyphenyl)methanone," Acta Crystallographica Section E, Vol. 67, No. 12, 2011, p. 3354. doi: $10.1107 / \mathrm{S} 1600536811048550$

[9] T. Muto, K. Sasagawa, A. Okamoto, H. Oike and N. Yonezawa, "[8-(4-Chlorobenzoyl)-2,7-dimethoxynaphtha-len -1-yl](2,4,6-trimethylphenyl)methanone," Acta Crystallographica Section E, Vol. 68, No. 3, 2012, p. 906. doi:10.1107/S1600536812008112

[10] A. Okamoto, D. Hijikata, N. Sakai and N. Yonezawa, "Poly (Arylene ether Ketone)s Composed of 1,8-Dia-roylenenaphthalene Moiety: A Non-Coplanarly Accumulated Aromatic-Ring Repeating Unit," Polymer Journal, 2012. doi:10.1038/pj.2012.135

[11] T. W. Greene, "Protective Group in Organic Synthesis," Wiley-Interscience, New York, 1991.

[12] M. Demuynck, P. D. Clercqand and M. Vandewalle, "(.+-.)-Hysterin: Revised Structure and Total Synthesis," Journal of Organic Chemistry, Vol. 44, No. 26, 1979, pp. 4863-4866. doi:10.1021/jo00394a025

[13] H. Niwa, T. Hida and K. Yamada, "A New Method for Cleavage of Aliphatic Methyl Ethers," Tetrahedron Letters, Vol. 22, No. 42, 1981, pp. 4239-4240. doi:10.1016/S0040-4039(01)82114-6

[14] G. A. Olah, S. C. Narang, B. G. Balaram Gupta and R. 
Malhotra, "Synthetic Methods and Reactions. 62. Transformations with Chlorotrimethylsilane/Sodium Iodide, a Convenient in situ Iodotrimethylsilane Reagent, "Journal of Organic Chemistry, Vol. 44, No. 8, 1979, pp. 1247-1251. doi.org/10.1021/jo01322a012

[15] R. Mitsui, K. Nakaema, K. Noguchi, A. Okamoto and N. Yonezawa, "1-(4-Chlorobenzoyl)-2,7-dimethoxynaphthalene," Acta Crystallographica Section E, Vol. 64, No. 7, 2008, p.1278. doi:10.1107/S1600536808017297

[16] K. Nakaema, A. Okamoto, K. Noguchi and N. Yonezawa, "1,8-Bis(4-chlorobenzoyl)-2,7-dimethoxynaphthalene,"
Acta Crystallographica Section E, Vol. 63, No. 10, 2007, p. 4120. doi:10.1107/S1600536807045114

[17] R. Mitsui, K. Nakaema, K. Noguchi and N. Yonezawa, "(4-Chlorophenyl)(2-hydroxy-7-methoxynaphthalen-1-yl) methanone," Acta Crystallographica Section E, Vol. 64, No. 12, 2008, p. 2497. doi:10.1107/S1600536808039603

[18] R. Mitsui, A. Nagasawa, K. Noguchi, A. Okamoto and N. Yonezawa, "1,8-Bis(4-chlorobenzoyl)-7-methoxynaphtha len-2-ol Ethanol Monosolvate," Acta Crystallographica Section E, Vol. 66, No. 7, 2010, p. 1790. 